\title{
Balina Şarkısı: kambur balina megaptera novaeangliae kültürlerinde müzikal pratikler
}

\author{
Dr. Öğr. Üyesi Ali Keleș
}

Sorumlu Yazar, Trabzon Üniversitesi Devlet Konservatuvarı, Müzikoloji Bölümü, Fatih Kampüsü, Akçaabat, Trabzon, e-Mail: akeles@trabzon.edu.tr, https: / /orcid.org/0000-0002-2332-5209

DOI 10.12975/rastmd.2021932 Submitted September 30, 2021 Accepted December 14, 2021

\section{Özet}

Erkek kambur balinalar (Megaptera novaeangliae) "şarkı" olarak adlandırılan uzun, karmaşık ve örüntüleșmiș seslendirme pratikleri sergilerler. Balina șarkılarının ișlevi henüz tam olarak anlașılamamıș olsa da hem bir kur davranıșı hem de diğer erkek bireylere çeșitli mesajlar veren bir iletișim biçimi olma ihtimali yüksektir. Balina șarkıları, hiyerarșik olarak düzenlenmiș çeșitli birimlerden ve tekrarlardan meydana gelir. Bu anlamda kambur balina șarkıları, hem düzenlenmiș/örüntüleșmiş yapısı ile hem de bireyler ve topluluklar düzeyindeki aktarımları nedeniyle balina kültürlerinin bir parçası olarak görülür ve insan müziği ile benzerlikler tașır. Bu makalenin amacı, balina şarkısı araştırmalarının ve zoomüzikolojik çalıșmaların bulgularını, vokal öğrenme çerçevesinde ve müziğe ilișkin kavrayıșlarımızla ilișkili biçimde sunmaktır. Bu amaca yönelik olarak çalıșmanın yaslandığı temel araștırma metodu, literatür taramasıdır. Deniz biyolojisi, biyoakustik, etoloji, zoomüzikoloji ve etnomüzikoloji gibi farklı disiplinlerin alanyazınları, hayvan müziği, vokal öğrenme ve balina şarkısı eksenlerinde incelenmiș ve konuya ilișkin bulgular derlenmiștir.

Anahtar Kelimeler

zoomüzikoloji, balina șarkısı, kambur balina, vokal öğrenme

\section{Giriș}

Müziğin insana özgü olup olmadığı veya diğer türlerin müziği olup olmadığı müzikologlar için, erken dönem karşılaștırmalı müzikoloji çalıșmalarından beri bir sorun olagelmiștir. Karşılaștırmalı müzikologlar, 20. yüzyılın başından itibaren tüm insan kültürlerinin müzikal ortaklıklarını (müzikal evrenseller) tespit ederek "müziğin kökeni nedir?" sorusunu yanıtlamaya çalıșmışlardır. Örneğin Carl Stumpf'un 1911 tarihli Müziğin Kökenleri kitabı, günümüzde halen üzerinde durulan ve artık disiplinlerarası bir perspektifle araștırılan, çeșitli konulara dikkat çekmiștir. Stumpf ile birlikte çalıșan ve Berlin Fonogram Arșivi'nin uzun yıllar müdürlügünü yapan Eric von Hornbostel, insan olmayan hayvanlarda müzikal tınısal biçimler üzerine fikir yürütmüş ve Musikpsychologische Bemerkungen über Vogelgesang (Kuş Ötüșü Üzerine Müzikal Psikolojik Açılamalar) adlı çalıșmasında karșılaștırma metodunun sınırlarını insan kültürlerinin ötesinde türler arası bir noktaya tașımıștır. Yine Berlin Fonogram Arșivi'nde Carl Stupmf ve Eric von Hornbostel'in asistanlığını yapan George Herzog'un 1941 tarihli "Hayvanlarda müzik var mı?" adlı metni, halihazırda felsefi ve gündelik düzeyde tartışılmakta olan (ve hatta çoğu zaman ötücü kușlar için bir önkabul ile ele alınan) "hayvan müziği" sorununa müzikolojik bir perspektiften yaklaşan ilk yayınlardan biri olmuștur. 
Karșılaștırmalı müzikologların bu öncü çalıșmaları, etnomüzikoloji açısından iki olgu nedeniyle kesintiye uğramıștır: (1) Boasçı antropolojinin ve kültürel göreliliğin baskın fikir haline gelerek karșıkültürel (ve dolayısıyla türler arası) analizleri gözden düşürmesi; (2) 1960’lardan günümüze dünyanın geçirdiği siyasal, kültürel dönüșümlerin, etnomüzikologları (tüm diğer sosyal bilimciler gibi) kimlik, toplumsal cinsiyet, ötekilik, küreselleșme, göç, diaspora vb. konulara odaklanmak durumunda birakması. Ancak son yirmi yılda, ekolojik problemlere giderek daha çok ilgi göstermeye başlayan etnomüzikologlar, (en azından nesli tükenme tehlikesi altında olan) insandișı türlerin müzikal pratiklerine de ilgi göstermeye bașlamışlardır.

Biyolojik çeșitliliğin hızla zarar gördüğü ve çevresel sorunların küresel bir hal aldığı günümüzde, insan merkezli bakış açısı, artık sosyal bilimcilerin dahi kurtulmaya çalıștığı dar bir çerçeve olarak görülmeye bașlamıștır. Bu bağlamda insanı ve insan topluluklarını, içinde yașadığı ekosistemlerin hâkimi olarak değil de etkin bir parçası olarak ele alan yaklaşımlar, yalnızca biyoloji gibi doğal bilimler için değil, aynı zamanda sosyoloji, antropoloji ve etnomüzikoloji gibi sosyal bilim dalları için de giderek geçerlilik kazanmaktadır. İște böyle bir toplumsal bağlamda zoomüzikoloji, yenilikçi ve disiplinlerarası yaklaşımı ile müziği, oldukça geniş bir bağlamda anlamlandırmaya çalışmakta ve etnomüzikologlara bakıș açılarını genișletmek için fırsatlar sunmaktadır. Zira Martinelli'nin de ifade ettiği gibi; "zoomüzikoloji, insan olmayan hayvanlara insan bilimleri yönünden, müziğe de biyolojik bilimler yönünden yaklașmaktadı" (2007:117). Doolittle ve Gingras, zoomüzikolojiyi basitçe insan olmayan hayvanlar arasındaki ses iletișiminin müzik benzeri yönlerinin incelenmesi olarak tanımlar (2015:811). Zoomüzikolojiyi zoosemiotik ile ilișkili biçimde değerlendiren Martinelli'ye göre disiplinin konusu, hayvanlar arasında sesli iletișimin estetik kullanımıdır (2005:3). Bu anlamda müzik benzeri davranıșlar sergileyen ötücü kușlar, bazı böcek türleri, çeșitli kara ve deniz memelileri özellikle ele alınan türlerdir.

Taylor'a göre zoömüzikologlar, insan müziği ve hayvanların müziğe ilișkin kapasitelerine yönelik bağlantılar kurar ve insan müziği ile hayvanların müzikal davranışları arasındaki süreklilikleri ortaya çıkarır. İnsan müziğinin çeșitli türlerinde eğitim almıș kișiler olarak zoomüzikologlar, araștırma konularına eğitimli bir kulakla yaklaştıkları için diğer uzmanların sormadığı sorular sorarak hayvan müziği araștırmalarındaki sorgulamanın çevresini değiștirmektedirler. Hayvan müziği olgusu standartlaștırılmış bir metodoloji veya sabit araștırma soruları olmadan çalıșıldığından zoomüzikoloji bir disiplinden ziyade çok perspektifli bir alan olarak kabul edilir. Zoomüzikoloji pratisyenleri, müzik yapmanın türler arasında paylașılan bir kapasite olduğu inancında birleșseler de araștırma temalarında, metodolojilerinde, teorilerinde ve interdisipliner ișbirliklerinde farklılık gösterirler. Etnomüzikoloji ise çalışma konusuyla değil ancak metodolojisiyle tanımlanma eğiliminde olduğu için bu anlamda zoomüzikolojiden farklılașır (2020:13-14).

Zoomüzikolojinin etnomüzikolojiye fazladan bir enerji enjekte edebileceğine ve 
onu daha heyecan verici bir çalıșma alanına dönüștüreceğine vurgu yapan Sorce-Keller yine de zoomüzikolojik çalıșmaların henüz etnomüzikoloji literatürüne yeterince yansımadığından yakınır. "Benim algıma göre, etnomüzikoloji alanında çalıșan birçok bilim insanı, zoomüzikoloji alanında kendileri için ne kadar çok șey olduğunun ve içlerinde ne kadar kolayca bağlantı kurabileceğimiz șeyler/kișiler olduğunun farkında olmayabilir. En azından okuyucularımın önemli müzikoloji veya etnomüzikoloji dergilerinde yayınlanmıș hayvan sesleri üzerine çok sayıda makaleyi kolayca hatırlayacağını sanmıyorum." (2012:166)

Etnomüzikoloji, müzikoloji ve zoomüzikolojinin birbirine en çok yaklaștığ araştırma konusu, ötücü kuşların şarkıları olmuștur. Etnomüzikologlar ve müzikologlar, insanların müzik kültürlerinde yer alan kuș mitoslarına, kuș șakımalarının toplumların müzikal yapılarında nasıl temsil edildiğine ya da onları nasıl etkilediğine dair (yine insan kültürü odaklı) araștırmalar yürütürken, biyologlar kușların vokal davranıșlarını anlamlı çerçevelere oturtmaya çalıșmışlardır. Günümüzde ise zoomüzikoloji ve biyomüzikoloji, kuşların müzikal kapasitelerine dair oldukça ilginç bulgular ortaya koyarak etnomüzikologları, "müzik” tanımlarını gözden geçirmeye zorlamaktadır.

Kuşların müzikal nitelikler taşıyan şakımalarına dair ilk bilimsel çalıșmalar, teknolojik yetersizlikler nedeniyle, ișitmeye ve notasyona dayalı biçimde yapılmıștır. 1950'lerden itibaren bașta William $H$. Thorpe olmak üzere ornitologlar, sonogram teknolojisini kullanarak, ötücü kuşların șakımalarındaki akustik yapıları daha objektif biçimde görselleștirmeyi bașarmıștır. Böylece kuș şakımalarının tamamen içgüdüsel olmayıp sosyal öğrenme ile bireyler ve kușaklar arasında aktarıldığı ispatlanmıștır. Ornitomüzikoloji (kușmüzikolojisi) terimini ilk kez 1962'de ortaya atan Peter Szöke, çeșitli kuș şakımalarının spektogram analizlerini yaparak bunların yapılanma karakteristiklerini ortaya koymuş ve daha sonraki analizler için belirli ötüş̧ biçimlerine karșılılık gelen çeșitli terimler önermiștir (kuş șarkılarındaki unsurların analizinde kullanılan terminoloji için bkz. Aydın 2020:49-50). Besteci François Bernard Mache ise kuș şakımalarının estetik niteliklerine vurgu yaparak, bu çalıșma alanını daha geniș perspektifteki bir zoomüzikoloji disiplini içinde ele almayı önermiștir.

Zoomüzikolojik araștırmaların odaklandığı bir diğer tür ise Güneydoğu Asya'nın yağmur ormanlarında yașayan, gibonlardır. Yașam alanları, insani faaliyetler nedeniyle giderek tükenen bu șebek türü, boynundaki kese sayesinde hayli yüksek volümde sesler üretir ve bu sesleri, üzerinde hak iddia ettiği alanın sınırlarını ișaretlemek için kullanır. Ancak diğer maymun türlerinden farklı olarak bu gibonlar, uluma benzeri örüntüleșmiș sesleri, eș düetleri ve aile şarkıları biçiminde icra ederler. Bir tür çağrı-yanıt tekniği ile inşa edilen gibon düetlerinde dișinin ve erkeğin farklı özelliklere sahip kendi partları mevcuttur.

Geissmann'ın (2000:107) dikkat çektiği üzere, erkek gibonlar, şarkı ilerledikçe yavaș yavaș daha karmașık hale gelen bir veya birkaç farklı kısa cümle türü üretir. Dișiler ise așağı yukarı düzenli aralıklarla, genellikle uzun çağrılar (great calls) olarak adlandırılan uzun, dișilere özgü ifadeler ekler. Erkekler genellikle her uzun çağrının başında seslendirmeyi 
bırakırlar ve daha yaygın olan kısa cümlelere devam etmeden önce uzun çağriya özel bir cevap cümlesi (koda) icra ederler. "Yetișkin erkek ve dișinin bașarılı bir düet için uyum/koordinasyon geliștirmesi gerekir ve bu, birlikte uzun bir çalıșma ve prova sürecini ve odaklanmayı gerektirir. Yavrular, 8,5-10 yıl kadar ebeveynleri ile birlikte yașarlar ve sonra kendi bölgelerini ve eșlerini bulmak için aileden ayrılırlar. Erkekler olgunlașmadan önce genellikle dișilerin șarkılarını söylerler” (Keleș 2021:13).

Ötücü kușlar ve gibonlara ek olarak son elli yılda çok büyük gelișmeler kat eden ve önemli bulgular ortaya koyan balina araștırmaları ise çoğunlukla biyologlar, biyoakustik uzmanları ve etologlar tarafından gerçekleștirilmiștir. $\mathrm{Bu}$ araștırmalar sırasında balinalar, tüm biyolojik ve davranışsal özellikleri ile ele alınmıștır. Balinaların vokal pratiklerine dair elde edilen bulgular, gerek bilim dünyasında gerekse de popüler gündemde yankı uyandırmıștır. Zoomüzikologlar, balinaların vokal pratikleri içinde özel bir yer tutan uzun, karmaşık, örüntüleșmiş ses dizileri yani "balina șarkısı"na odaklanırlar. Bu uzun, karmașık ve yapılașmış sesler, tıpkı daha önce ötücü kuș șarkılarının sebep olduğu gibi, hem insanın müzikal kapasitesini bașka canlı türleri ile paylașıp paylașmadığına hem de müziğin nasıl tanımlanması gerektiğine dair müzikolojik, insanbilimsel ve felsefi sorulara yol açmaktadır. Zoomüzikoloji bir yandan da bu soruların yanitlanması çabasıdır.

Kendi içinde çeșitli özelliklerine göre sinıflandırılan tüm deniz memelileri, belirli vokal sesler üretirler. Yunuslar ve dișli balinalar sınıfına dahil olan alt türler (örneğin orkalar ve ispermeçet balinaları), bu vokal sesleri, iletișim ve ekolokasyon amaçlı kullanırlar. Ekolokasyon, nesneleri tanımlama ve onların yerlerini tespit etmek için ses dalgalarının kullanılmasıdır. Hem doğada (yarasalar, yunuslar vb.) hem de teknolojik cihazlarda (denizaltılar) kullanımı mevcuttur. Işığın ulașamadığı derin sularda ses (özellikle yüksek frekanslı kliklerden oluşan ve Mors alfabesini andıran sesler); yön bulma, nesnelerin ve avların yerini tespit etme ve iletișim kurmada, görme duyusundan çok daha işlevseldir. Dolayısıyla bu türler, tıpkı yarasalar gibi, söz konusu yüksek frekanslı sesleri, etkin biçimde kullanabilmeküzere evrim geçirmişlerdir.

Çeșitli balık türleri ve penguen ya da fok gibi memelilerle beslenen dișli balinaların aksine çok küçük deniz kabukluları ve küçük sürü balıkları ile beslenen diğer balina türleri ise dișsiz ya da çubuklu balinalar (baleen whales) olarak adlandırılır. Mavi balina, kambur balina, güney gerçek balinası vb. türleri barındıran bu sınıfın biyolojik özelliği; ağızlarında diş yerine ince, çubuksu yapılara sahip olmalarıdır. Bu çubuksu yapılar, beslenme sırasında büyük miktarda su ile birlikte alınan küçük deniz kabuklularının süzülmesini ve böylece sudan ayrıștııılmasını sağlar.

Çubuklu balinaların bir diğer özelliği yukarıda bahsi geçen klik seslerden çok dahakarmașıkveuzun seslerüretmeleridir. Özellikle kambur balinaların (megaptera novaeangliae) bu karmașık vokal pratikleri, 1970'lerin bașından itibaren, bilim dünyasının ilgisini çekmektedir ve bu bağlamda incelenen uzun, karmaşık ses örüntüleri "balina șarkısı" (whale songs) olarak adlandırılmaktadır. 
$\mathrm{Bu}$ makalenin amacı, balina șarkısı araștırmalarının ve zoomüzikolojik çalıșmaların bulgularını, vokal öğrenme çerçevesinde ve müziğe ilișkin kavrayıșlarımızla ilișkili biçimde sunmaktır. Bu amaca yönelik olarak çalıșmanın yaslandığı temel araștırma metodu, literatür taramasıdır. Hayvanların müzikal davranıșları ve kambur balinaların vokal pratikleri konusu hem tarihi boyunca hem de günümüzde farklı disiplinlerce ele alındığından, araștırma sürecinde farklı disiplinlerin alanyazınları incelenmiștir. Örneğin biyoloji ve deniz biyolojisi literatürü kambur balinaların taksonomisi, fizyolojik özellikleri için gözden geçirilmiștir. Öte yandan balina kültürü olarak adlandırılan, sosyal öğrenmeye dayanan ve kușaklar arasında aktarılan çeșitli davranıș kalıplarının anlașılabilmesi için ise etoloji araștırmalarının sonuçları incelenmiștir. Literatür taraması sırasında vokal öğrenme ve tınısal düzenlilikleri ișleyebilme gibi bilișsel beceriler ve bunların insan dıșında hangi türlerde mevcut olduğu bir bașka araștırma bașlığı olmuştur. Bunlara ek olarak kambur balina şarkılarını müzikolojik bir bakışla tartışabilmek için hem kambur balinaların hem de daha geniș düzeyde vokal pratiklere sahip diğer canlı türlerinin müzikolojik perspektifle değerlendirildiği bir alan olarak zoomüzikoloji literatürü incelenmiștir. Literatür taraması sonucunda elde edilen bulgular doğrultusunda ilk bölümde deniz memelileri hakkında genel bilgiler ve bu sinıfa dahil olan kambur balinanın taksonomik konumu ile biyolojik özellikleri anlatılacaktır. Daha sonra kambur balina kültürünü olușturan bazı davranıș kalıplarından örnekler sunulup bu kültürün en ilgi çekici yanını olușturan vokal pratikler ve "balina şarkısı" işlenecektir. Vokal öğrenme bașlıklı bölümde ise kambur balina şarkılarının "vokal öğrenme" kavramı çerçevesinde değerlendirilmesi durumu tartışılacaktır.

\section{Biyolojik Taksonomi ve Bedensel Özellikler: Kambur Balina Türü/ Ailesi}

Taksonomik olarak kambur balina ailesi (megaptera novaeangliae); yunusları, balinaları ve musurgilleri içeren deniz memelileri takımının (order cetacea) içinde bulunan çubuklu balinalar alttakımındaki (suborder mysticeti) on dört balina türünden biridir. Bu alttakım, kambur balinalara ek olarak gri balina, mavi balina ve Grönland balinası gibi diğer dișsiz türleri de barındırır. Yaklașık yetmiș beș farklı türü barındıran dișli balinalar alt-takımında (suborder odontceti) ise kuzey şișe burunlu balinası, ispermeçet balinası ve katil balina gibi türler bulunur.

Ortalama ömrü 60 yıl olan ve yașayan en büyük hayvan türleri arasında yer alan kambur balinaların ortalama boy ve ağırlıkları sırasıyla 15 metre ve 30 ton civarındadır. Dünyanın farklı bölgelerindeki sürülere dair verileri değerlendiren Clapham ve Mead, dișilerin genel olarak erkeklerden 1 - 1,5 metre daha uzun ve ağır olduğunu saptamıștır (1999:2).

Kambur balinaların bir bașka fiziksel özelliği ise başını ve alt çenesini kaplayan yumrulardır. Tüberkül olarak adlandırılan bu yumruların her biri sert bir kıl içeren, kıl kökleridir. Bu kılların sudaki hareketlere dair duyusal bilgi sağladığı düşünülmektedir. Bir bașka 
deyișle bu yumru yapılar tıpkı kedigillerin bıyıkları gibi bir ișleve sahiptir (Perrin vd, 2002:1370).

Kambur balinalar, diğer bazı balina türleri ile paylaștıkları koyu renkli sırtları ve yumrularının yanı sıra belirgin sirt kamburları, ok ucu biçimli kuyrukları ve boyutları 5 metreye kadar ulașan büyükön yüzgeçleri gibi çeșitli fiziksel özellikleri sayesinde yakın akraba türlerden kolayca ayırt edilebilir. "Eski Yunanca dev kanat sözcüklerinden türetilen Megaptera genel $\mathrm{ad}$, onların büyük ön yüzgeçlerini ifade eder. Spesifik isim novaeangliae ise 'New Englandlı' anlamına gelir ve muhtemelen ABD'nin kuzeydoğusundaki New England kıyılarının açıklarında düzenli olarak görülmeleri nedeniyle verilmiștir" (Clapham ve Mead, 1999:6). Koyu renkli sırtlarının aksine kambur balinaların gövdelerinin yanları, alt kısmı ve kuyrukları beyazdır. Brodie'ye göre yüzgeçlerdeki beyaz renk, balık sürülerini korkutmak ve belirli bir yöne doğru gütmek için kullanılmaktadır (akt. NMFS 1991:5). Kuyruğun tırtıklı kenarları ve açık renkli kısımlar, tüm kambur balina bireylerinde kendine özgü desenler olușturur. Araștırmacı ve gözlemciler, bu desenler sayesinde bireyleri takip edebilmektedir. Zira avlanmak ve beslenmek üzere, bedenlerini ve kuyruk desenlerini görünür kılacak biçimde, su yüzeyine çıkmak ve sıçramak, kambur balinaların sık sergilediği akrobatik davranıșlar arasındadır.

\section{Kambur Balina Topluluklarında Öne Çıkan Davranıș Kalıpları}

"Kambur balinalar dünya çapında tüm büyük okyanuslarda bulunur. Genellikle kıta sahanlığı alanlarını tercih etseler de derin açık deniz sularını geçtikleri ve açık okyanusta deniz dağlarının üzerinde ve çevresinde zaman geçirdikleri de bilinmektedir" (Link 1: https://iwc.int/ humpback-whale). "Kambur balinalar (Megaptera novaeangliae), kutup altı sulardaki yüksek enlemlerde bulunan yaz beslenme alanları ile tropik sulardaki düșük enlemli kıș üreme alanları arasında geniş yıllık göçler gerçekleștiren oldukça göçmen bir türdür" (Dawbin'den akt. Martin vd. 2021:1). Kimi zaman 5000 mil gibi uzun göçler sergileyen kambur balinalarda tüm bireyler her yıl göç etmez. Göç davranışının amacı henüz tam olarak netleșmemiş olsa da yazın yüksek enlemlerdeki yiyecek bolluğundan faydalanmak ve kışın daha sıcak olan ekvatora yakın sığ bölgeleri üreme alanı olarak kullanmak için göç ettikleri düșünülmektedir (bkz. Clapham, 2002:589-590).

Sosyal örgütlenme anlamında küçük ve akıșkan gruplarla karakterize olan kambur balinalar, tipik olarak hem beslenme hem de üreme alanlarında birçok farkl birey ile ilișki kurar. Bölgelerini savunma eğiliminde olmayan bu türün görece uzun vadeli ilișkiler sergileyen topluluklarında akrabalık önemli bir belirleyici değildir. Öte yandan yalnızca kambur balinalara özgü olan ve popülasyonlar arasında sosyal öğrenme ile yaygınlaşan "baloncukla avlanma" bir kolektif av davranıșıdır ve beslenme alanlarında bazı kararlı grupların olușmasını sağlamıștır. Baloncukla avlanma sırasında balinalar, "balık sürülerinin etrafına veya altına baloncuk üflerler. Bu baloncuklar merkeze doğru giderek daralan spiral biçimli bir perde olușturarak sürüyü yönlendirir. Kambur balina ağzı açık vaziyette kabarcık yapısının merkezine doğru hamle yaparak büyük miktarda av ve suyu ağzına alır" (Clapham, 2002:591). Deniz biyologları 
ve etologların ilgisine çeken bir diğer davranış sıçrama ve bedeni okyanus yüzeyine çarparak su sıçratmadır. Oyun ve eğlenceyi anımsatan bu davranış, iki buçuk milden daha uzaktaki kambur balina gruplarına seslenmenin yollarından biridir ve bir grubun bölünmesi ya da grupların bir araya gelmesi için iletișim sağlamaktadır. Dolayısıyla sıçrama ve su sıçratma gibi "yüzey aktif davranıșlar öncelikle sosyal faktörlerden etkilenir ve sosyal bir ișleve sahiptir" (Kavanagh vd. 2016:315). Türe ve popülasyonlara özgü bu sosyal davranıșlardan bir diğeri ise kambur balinaların doğada eșine az rastlanır çağrı repertuarı ile karmaşık ve uzun vokal seslendirmeleridir. Balina șarkısı olarak anılan bu vokal pratikler, kambur balinaları, zoomüzikolojinin ilgi alanlarından biri haline getirmiştir.

\section{Kambur Balinaların Vokal Pratikleri}

Tüm deniz memelileri gibi balinalar da çeșitli vokal sesler üretir. Ancak balinaların ses telleri yoktur ve bu nedenle bilim dünyasında yakın döneme kadar tamamen sessiz canlılar oldukları fikri yaygın olagelmiștir. Günümüzde ise balinaların ses tellerine ihtiyaç duymadan hem frekans ve yeğinlik hem de tınısal çeșitlilik anlamında çok farklı sesler üretebildikleri anlașılmıștır. Ancak vokal pratikler sırasında balinaların bedenlerinin içini gözlemlemek mümkün olmadığı için seslerin nasıl üretildiği halen netlik kazanmamıștır. Hipotezler ve biyoakustik alanındaki güncel çalıșmalar, balinaların havayı dıșarı üflemek yerine, solunum sisteminin içindeki tüplerde ve nazal boșluklarda hareket ettirerek ses üretebilecek bir fizyolojik mekanizmaya sahip olduğunu söylemektedir (bkz. Adam vd. 2013).

Kambur balinalar, okyanuslarda yașayan en karmașık vokal repertuarına sahip canlı türlerinden biridir. Bu vokal repertuarın bir kısmını tüm kambur balina bireylerinin ürettiği, görece kısa ve basit yapılı çağrılar (call) olușturur. Bu sosyal çağrılar; erkek, diși, yavru ya da yetişkin olsun tüm kambur balina bireyleri arasında iletișim amaçlı üretilen seslerdir. Örneğin yavru kambur balinalar, "olasılıkla yırtıcılar tarafından duyulmaması için fisıltiya benzer kısık sesler çıkarır" (Welch, 2021:39). Deniz biyoakustiği alanında doktora yapan Michelle Fournet'nin odaklandığ çalıșma konusu, kambur balinaların vokal repertuarı ama özellikle de șarkı dıșı olarak kategorize edilen bu kısa sosyal çağrılarıdır. Vokal çağrı tiplerini on altı farklı sinıfta kategorize eden Fournet'ye göre; kambur balinaların sesli davranışları sosyal bağlama göre değișmektedir ve sosyal etkileșim potansiyeli arttıkça vokal pratikler karmașıklașma eğilimi göstermektedir. Dolayisiyla bu bulgular, mekânsal ve mevsimsel olarak değișen karmașık sosyal etkileșimler ve örgütlenmeler sergileyen kambur balinaların, vokal çağrıları, iletişimsel bir amaçla kullandığı hipotezini güçlendirmektedir (Fournet, 2014).

\section{Kambur Balina Şarkısı}

Kambur balinaların kısa ve basit sosyal çağrılarına ek olarak vokal repertuarının ikinci ve daha ilginç kısmında ise yalnızca erkek bireylerin yaydığı, süresi 5 ile 30 dakika arasında değișen ve hassasiyetle tekrarlanan uzun, karmașık ve yapılandırılmıs ses dizileri bulunur. Bilimsel alanyazında balina șarkısı (whale song) olarak tanımlanması kabul görmüş olan bu ses dizileri; düzenli biçimde bir araya getirilmiș "yüksek perdeli gıcırtılardan, orta frekanslardaki ötüș ve çığlıklardan, düşük frekanslı cırıltı ve 
kükremelere kadar çok çeșitli seslerden ve bunların kombinasyonlarından meydana gelir" (Darling, 2002:1124).

\section{Balina Şarkısı Araștırmalarına Dair Kısa Bir Tarihçe}

Kambur balinaların vokal seslendirmelerine dair ilk ses kayıtları, 1950’lerin bașına dek uzanır. İkinci dünya savașı sonrasında, soğuk savaș koșulları altında, anti-denizaltı çalıșmaları kapsamındaki askeri sualtı dinleme faaliyetleri, balina şarkılarının ilk kayıtlarını sağlamıștır. 1952'de Hawaii açıklarındaki hidrofon tesisi tarafından alınan ilginç ses kayıtlarının (su altında yayılan uzun inleme ve feryat benzeri sesler) kambur balinalara ait olduğu ise daha sonra tespit edilmiștir. Bermuda açıklarındaki benzer bir askeri hidrofon tesisinde, Rus denizaltıların dinleyen donanma mühendisi Frank Watlington ise 1953-1964 yılları arasında kambur balinaların vokal seslendirmelerini kaydetmiștir. Watlington'ın aldığı ses kayıtlarına ulașan biyo-akustik uzmanı Roger Payne ve eși Katherine Payne, söz konusu seslendirmelere balina șarkısı adını vermiș ve bu vokal pratiklere yönelik sistematik çalıșmaları bașlatmışlardır (bkz. Payne and McVay, 1971:585). Payne ve McVay, kambur balinaların vokal pratiklerindeki düzenliliğe ilk kez dikkat çeken bilimsel yayının sahipleridir ve çalıșma șu ifade ile açılır: "Kambur balinalar, insanların duyabileceği frekanslarda, uzun, öngörülebilir kalıplarda sesler yayar" (1971:585). Bu öncü yayının ardından "Bermuda ve Batı Hint Adaları'ndaki kambur balinalardan kaydedilen sesleri analiz eden Winn vd. ise biraz daha farklı bir yaklașımla da olsa 'balina şarkısı' yaklașımını desteklemiștir. Winn vd. inceledikleri seslerin örüntüleșmiș diziler içerdiğini ve bunların karakteristiklerini göstermiștir" (Cholewiak ve Sousa-Lima, 2013:314).

Yukarıda bahsi geçen öncü çalıșmaların ardından kambur balinaların vokal pratikleri ve șarkıları; ișlev, zamansal değișim, hiyerarșik yapılanma, karmașıklık ve anlam bakımından pek çok araștırmanın konusu olagelmiștir. Disiplinlerarası bir yaklașıma ihtiyaç duyan bu araștırmalar günümüzde; etoloji, deniz biyolojisi, evrimsel antropoloji, biyoakustik, zoomüzikoloji, etnomüzikoloji, dilbilim ve kognitif psikoloji gibi pek çok alandan biliminsanını kendine çekmeye devam etmektedir.

\section{Kambur Balina Şarkısının Yapısı}

Kambur balinaların uzun ve karmașık vokal seslendirmelerine "șarkı" denmesinin nedeni, daha önce de belirtildiği gibi, hiyerarşik olarak düzenlenmiş çeșitli birimlerden (ses dizilerinden) ve tekrarlardan meydana gelmiş olmalarıdır. Bir kambur balina șarkısında nota benzeri "tekil birimler (unit) ${ }^{1}$ art arda gelerek cümleleri (phrase), bir araya gelen cümleler ise temaları (themes) olușturur. Belirli biçimlerde düzenlenen ve tekrar eden temalar ise șarkıları (song) meydana getirir" (Marcedo, Herman vd, 2005:94). "Bir temadan diğerine geçmek için, bazen önceki ve sonraki temalardan öğeler içeren tek bir 'geçiş cümlesi' söylenir" (Payne ve Payne'den akt Garland vd. 2017:7822). Şarkının defalarca icra edildiği bir performans ise șarkı seansı (song session) olarak adlandırılır. “Tipik bir șarkı altı tema içerebilir. Bir şarkıcı 1-2-3-4-5-6 temalarında şarkı

1 Lois K. Winn ve Howard Winn gibi bazı araștırmacılar bu tekil ses birimlerini "hece" (syllable) biçiminde isimlendirmiștir. 
söyleyebilir ve ardından tekrar 1'den bașlayabilir. Bir şarkıdaki temaların sayısı popülasyondan popülasyona ve yıldan yıla değișir. Bir șarkı seansı saatlerce ara vermeden devam edebilir" (Darling, 2002:1124). Payne ve McVay, kambur balina șarkılarını barındıran ses kayıtlarını sonogram teknolojisini kullanarak görselleștirmiş ve șarkıların hiyerarșik yapılanmasını daha kolay algilanabilir hale getirmișlerdir (bkz. Figür 1). Günümüzde sonograma ek olarak balinaların ürettiği seslerin spektrum analizlerine de imkân sağlayan spektogram görüntüleri (bkz. Figür 2) ve bunlardan hareketle geliștirilen grafik notasyonlar da kullanılmaktadır.

SONG SESSION

DURATIONS

HOURS

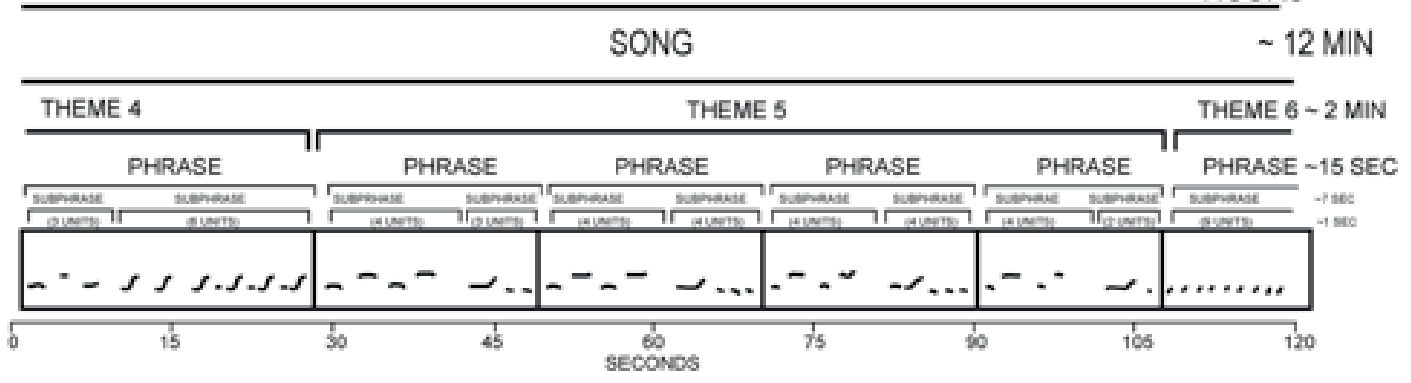

Figür 1. Kambur Balina Şarkısının Hiyerarșik Yapısı

(Payne ve McVay'in çalıșmalarından hareketle yeniden olușturulmuștur)

(Kaynak: https://www.hmmc.org/Song/HBWsong.html)

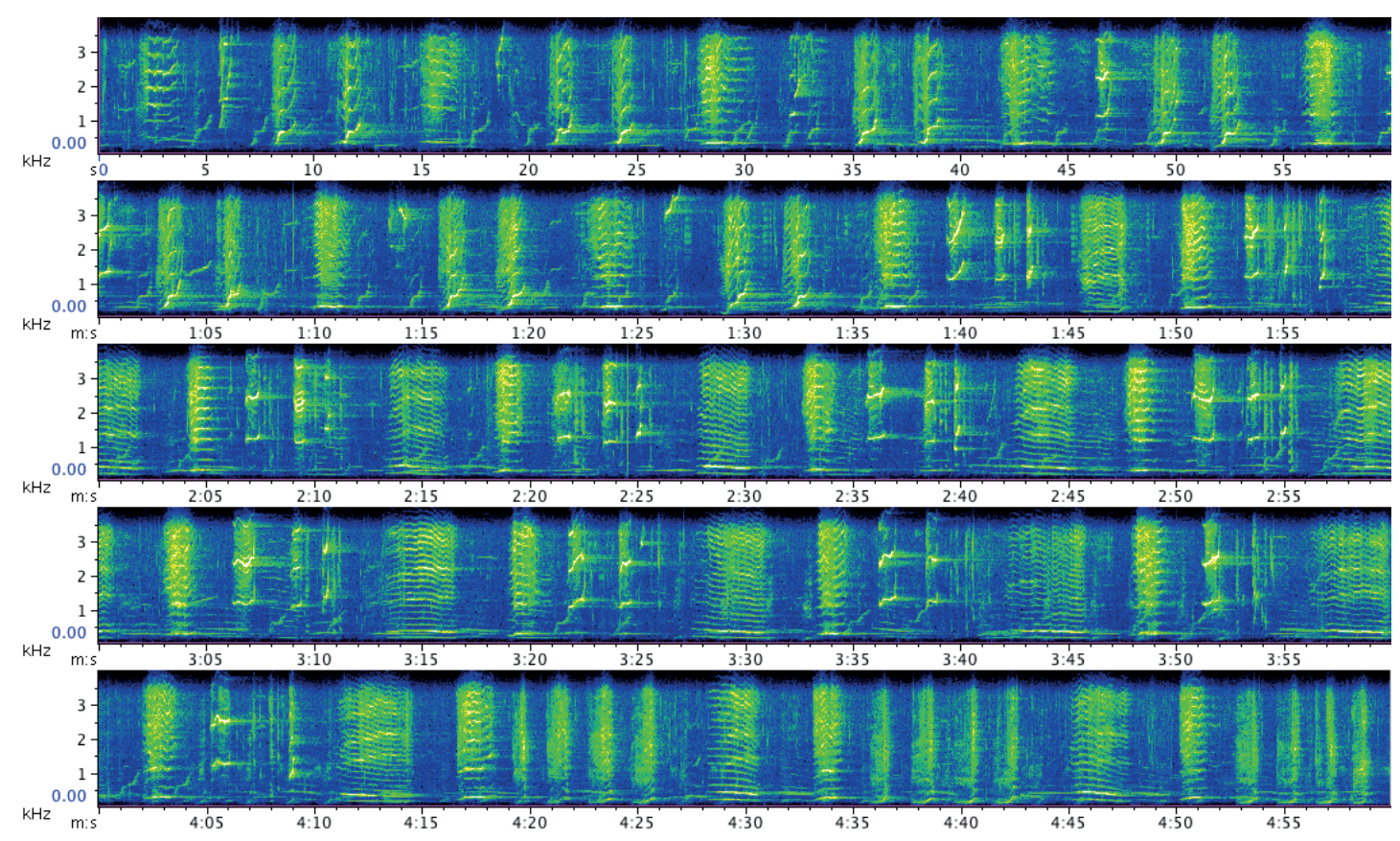

Figür 2. Bir kambur balina șarkısının 5 dakikalık bölümünün spektogram görüntüsü.

(Kaynak: https://www.hmmc.org/AudioGallery/AudioGallery.htm) 


\section{Șarkıda Kademeli Değișimler ve Devrimler}

Kimi zaman saatler sürebilen șarkı oturumlarını icra eden erkek kambur balinalar performans sırasında "çoğu zaman yalnızdırlar ve tipik olarak su altında 20-30 m derinlikte baș așağı eğik olarak sabit dururlar. Bazen bir erkek, diğer ses çıkarmayan balinalara (çoğu zaman bir anne/yavru çifti) eșlik ederken șarkı söyleyebilir" (Herman vd, 2013:1654). Șarkı söyleyen erkekler yalnız olsalar da okyanus suyunun sesi iletme kapasitesi ve kambur balinaların yüksek sesli icraları sayesinde aynı topluluktaki ya da komșu popülasyonlardaki erkek kambur balinalar da bu şarkıları ișitebilir/dinleyebilir.

Aynı toplulukta ya da birbirine yakın popülasyonlarda bulunan erkek kambur balinalar, belirli bir zaman dilimi içinde, aynıșarkıyısöylerler. Ancakses birimlerinin biçim değiștirmesi, sıralamanın veya tekrarların değiștirilmesi ya da komșu popülasyonlardan alınan parçaların şarkılara eklemlenmesi gibi davranıșlar nedeniyle șarkılar giderek karmașıklașır ve zaman içinde tamamen yeni șarkılara dönüșür. Kambur balina șarkılarının bu sürekli ve kademeli dönüșümü, insan dișı hayvan dünyası için benzersiz bir özelliktir. Kambur balina bireyleri farkl sesleri ve ses düzenlemelerini, yeni ifadeler ve temalar olușturmak için kullanır. Bunlar yavaș yavaș șarkıya dahil edilirken eski kalıplar kaybolur. Birkaç yıl sonra şarkı, orijinal versiyona artık çok az benzerlik gösterecek derecede değișebilir.

Darling'in de dikkat çektiği gibi şarkılar söylendikçe değișir. Bir bașka deyișle așamalı değișiklikler sezon dıșında değil, şarkı söyleme veya üreme mevsimi sırasında meydana gelir. Örneğin, kıș ilerledikçe, belirli bir cümledeki bir birim giderek daha az duyulurken diğeri daha yaygın hale gelebilir veya bir cümlede ayrı olan iki birim tek bir ses olarak birleștirilebilir. Bu küçük değișiklikler sonunda yeni ifadelere ve temalara yol açabilir. Şarkı söylenmeyen yaz mevsimi boyunca, șarkı nispeten sabit kalır, sonraki sezon șarkı icraları bașladığında dönüșüm de tekrar bașlar (2002:1124).

Șarkılardaki bu değișim sürecine kimi araștırmacılar bireysel düzlemde yaklaşırken diğerleri ise popülasyonlar arasındaki kültürel aktarım süreçlerine odaklanır. Örneğin Arraut ve Vielliard (2004), bir kambur balina popülasyonunun çiftleșme ve yavrulama alanı olan Brezilya, Abrolhos Bank'de gerçekleștirdikleri gözlemlerde șarkıların bestelenmesi, modifiye edilmesi ve karmașıklașması süreçlerindeki bireysel farklara odaklanmıșlar ve ilginç sonuçlar elde etmișlerdir. Buna göre popülasyondaki tüm șarkıcı erkeklerin paylaștığı bir güncel versiyon vardır. Ancak kimi bireyler, bu șarkının içerdiği bazı basit ses birimlerini (nota) modifiye ederek daha karmașık hale getirmekte, bazı temaları kullanmayı bırakmakta ya da șarkının tematik organizasyonunda değișiklikler yapmaktadır. Popülasyonun diğer șarkıcı erkek üyeleri de bu değișiklikleri kendi icralarına dahil etmektedir. Sonuç olarak kambur balina topluluklarındaki bazı bireyler, yeni șarkılar bestelemede ya da yeni ortaya çıkmıș kompleks notaları öğrenip icra etme konusunda daha yetenekli olabilir. Üreme mevsiminin erken așamalarında yeni veya daha karmaşık bir şarkıyı söyleyebilmek müzikal yeteneğin ya da hızlı öğrenme becerisinin sergilenmesi olabilir. Böyle bir beceri sergileme davranıșı, söz konusu bireyleri, cinsel açıdan (ya da 
diğer erkeklerle geliștirecekleri sosyal etkileșim ve statü ilișkileri açısından) daha çekici kılıyor olabilir. Diğer bir açıdan ise bireysel müzikal beceriler, kur davranışı ve eș seçimi konusunda etkili olarak popülasyonlar (ya da erkek bireyler) üzerinde müzikal yenilikler yapma yönünde baskı olușturuyor olabilir. Tabi ki balinaların yașam alanları (derin okyanus suları) ve çok geniș alanlara yayılan göç davranıșları gibi faktörler göz önüne alındığında bu hipotezi yeterli gözlemle test edebilmek oldukça güçtür. Kambur balina şarkısında bireysel becerilere benzer bir çerçeveden yaklașan Allen vd. zebra ispinozlarının kur sarkılarından hareketle oluşturulan "bilișsel kapasite hipotezi"nin kambur balinalar için de geçerli olup olmadığını sorarlar: "Bu sav, oldukça karmaşık șarkıların daha gelișmiş bilișsel yeteneklere ișaret edebileceğini ve dolayısıyla daha karmașık șarkılara sahip erkekler için dișilerin cinsel seçimini yönlendirebileceğini öne sürer" (2018:1).

Kambur balina șarkılarının dönüșümüne Avustralya kıyılarındaki popülasyonlar düzeyinde yaklașan Michael Noad, Ellen C. Garland ve meslektașları ise şarkılarda batıdan doğuya doğru sürekli bir kültürel aktarımın gerçekleștiğini tespit etmișlerdir. Avustralya'nın batı kıyılarındaki çiftleșme ve üreme alanlarında icra edilen șarkıların yalnızca birkaç mevsim içinde doğu kıyılarındaki kambur balinalar tarafından söylenmesi kambur balina șarkısı için bir "kültürel devrim"in ilk kez dile getirilmesini sağlamıștır (Noad, Cato vd, 2000:537). Ekip, 1998 ve 2008 yilları arasında Avustralya'nın doğu kıyısından Fransız Polinezyası'na, yaklașık altı bin kilometre doğuya kadar olan yerlerde yapılan kayıtları kullanarak farklı renklerle isimlendirdikleri şarkıların, daha doğudaki popülasyonlarda nasıl bir tür moda haline geldiğini göstermiștir. Özellikle mavi șarkının yayılımı ilginçtir (bkz. Figür 3). Şarkıların daha doğudaki popülasyonlar tarafından temellük edildiği bu hızlı dönüșümler, benzer yaș grupları ya da aynı jenerasyona dahil olan ilgisiz bireyler arasında gerçekleșen geniş ölçekli bir "dinamik yatay kültürel aktarım” biçiminde tanımlanmıștır (Garland, Goldizen vd, 2011:687). Söz konusu hızlı kültürel dönüşümü Beatles'ın Atlantik'i geçerek tüm Amerikan müzik yașamını değiștirmesine benzeten Whitehead ve Rendell'a göre; Güney Pasifik kambur balina șarkılarının neden batıya değil de doğuya doğru yayıldığı halen yanıt bekleyen önemli bir sorudur (2015:81).

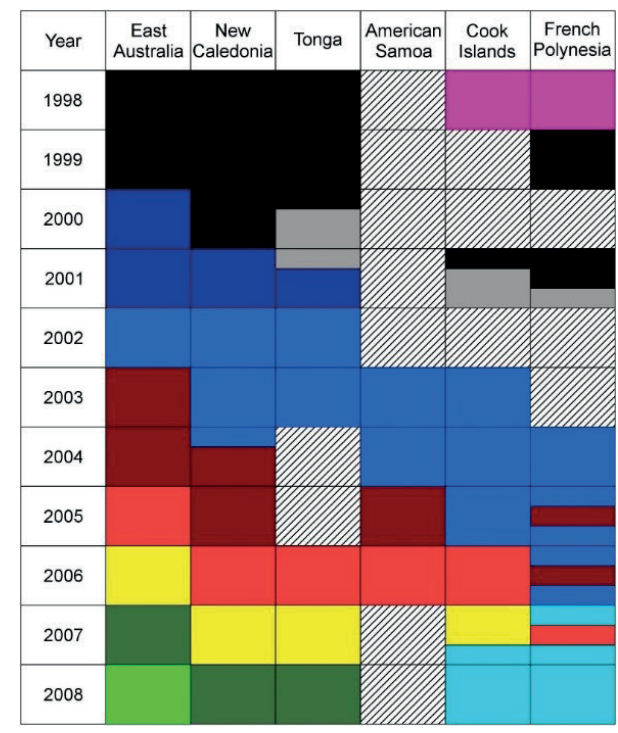

Figür 3: 1998-2008 yılları arasında Güney Pasifik'de tespit ve takip edilen șarkı tipleri. ${ }^{2}$ (Kaynak: Garland, Goldizen vd, 2011:687)

2 Popülasyonlar batıdan doğuya doğru (Doğu Avustralya'dan Fransız Polinezyası'na) listelenmiștir. Her bir renk farklı bir șarkı türünü temsil eder. Aynı yıl ve konum içindeki iki renk, her iki şarkı türünün de mevcut olduğunu gösterir. Çapraz taralı çizgiler mevcut veri olmadığını gösterir. 
Kambur balina șarkılarında gerçekleșen bu devrim niteliğindeki hızlı dönüșümler aynı zamanda iki olgunun daha tespit edilebilmesini sağlamıștır: segmentasyonun kullanımı ve hızl dönüșümlerin șarkıları basitleștirmesi. Kambur balinalar yeni şarkıları öğrenme sürecinde, hem eski hem de yeni șarkıdan unsurlar barındıran "melez şarkılar" icra etmektedirler. Bu bilgi kambur balinaların yeni șarkıları öğrenirken tıpkı insanların dil öğrenme sürecindeki gibi, segmentasyon mekanizmasını kullandığını göstermektedir. "İnsanın dil öğreniminde önemli bir mekanizma olan segmentasyon, sekansların daha sonra yeniden birleștirilebilecek daha küçük bileșenlere (kelime öbekleri veya kelimeler) bölünmesidir" (Garland, Rendell vd. 2017:7823); Daha önce bahsedildiği gibi kambur balina șarkıları mevsim boyunca icra edildikçe giderek gelișir. Hızlı dönüșümleri ișaret eden șarkı devrimleri sırasında ise kambur balina șarkılarının istikrarlı biçimde basitleștiği gözlemlenmiștir: "Şarkılar geliștikçe karmașıklık artmıș, bu da daha fazla ses birimi, birim türü ve tema içeren daha uzun șarkılarla sonuçlanmıștır. Devrimlerin ardından ise karmaşıklık azalmıștır: yeni şarkılar daha kısadır ve daha az birim, birim türü ve tema içermektedir" (Allen, Garland vd., 2018:3). Şarkılardaki bu basitleșme muhtemelen kambur balinalarda yeni materyallere yönelik sosyal öğrenme kapasitesinin sınırlarını ișaret etmektedir.

\section{Şarkının İșlevi}

İşlevi henüz tam olarak anlaşılamamış olsa da çoğunlukla ekvatora yakın üreme alanlarında sergilenmesi nedeniyle kambur balina şarkıları seksüel seçilim ve grup içi etkileșim ile ilișkilendirilmiștir.
Bir bașka deyișle kambur balina șarkılarının (tıpkı kuș șakımaları gibi) hem bir kur davranıșı hem de diğer erkek bireylere çeșitli mesajlar veren bir iletişim biçimi olma ihtimali yüksektir.

Erkek kambur balinaların şarkı söyleme pratiklerinin üzerinde en çok uzlașılan ișlevi, tıpkı kuşlarda olduğu gibi potansiyel eșlere (yani dișilere) sağlıklı olduklarını sergilemektir. Yani bu bir kur davranıșıdır. Öte yandan "erkek șarkıcıların diși balinalara katılıp eșlik ettiğine dair çok az șüphe olsa da dișilerin șarkı performanslarından etkilenip gönüllü biçimde șarkıcı erkeğe katıldığına dair henüz net bir kanıt yoktur" (Darling, 2002:1125).

Bu konuda bir bașka hipotez dișilerin doğrudan bu şarkıdan etkilenmedikleri ancak erkek balinaların konumlarını böylece bilebildikleri yönündedir. Dahası erkek balinalar yavrulama ya da çiftleșme mevsimleri dıșında yiyecek ararken ve avlanırken de șarkı söylemeyi sürdürürler. Ișığın olmadığı ortamlarda bu șarkıların kolektif çalıșmayı sağladığı düșünülebilir. Dolayısıyla yiyecek arama ve av șarkıları, insanların iș ve av şarkıları/dansları gibi işlev görüyor olabilir.

Clapham, başarılı bir șekilde rekabet edemeyen erkeklerin bunun yerine şarkı söyleyebileceğini öne sürerek, şarkıcıların erișkinliğe ulașmamış genç erkekler olduğunu ima etmiștir. Bir bașka deyișle olgunlașmamıș erkekler, șarkı gösterimleri sayesinde, daha sonraki yıllarda yararlı bir șekilde uygulayabilecekleri kışlı alanların sosyal, davranıșsal ve akustik becerilerini ve geleneklerini öğrenme ve uygulama fırsatlarının artmasıyla ertelenmiş 
faydalar elde edebilirler. Buna karșın Darling, șarkı performansının çiftleșme yarıșında ortak bașarıyı teșvik etmek için bir șarkıcı ve bir eșlikçi arasında ittifaklar yaratmaya hizmet edebileceğini savunmuștur (bkz. Herman vd).

Sonuç olarak kambur balina șarkısının işlev(ler)i henüz net biçimde ortaya çıkarılamamış olsa da bu konudaki hipotezler șöyle sıralanabilir: Kambur balinalar; alanlarını ișaretlemek için, cinsel anlamda daha çekici olmak için, göçleri koordine edebilmek ve uygun biçimde konumlanmak için, diğer üyelerle iletișim kurabilmek için șarkı icra ederler. Ancak erkek kambur balinaları şarkı söylemeye iten bașlıca sebebin "eğlence" olması da muhtemeldir. Zira tıpkı insanın müzikal faaliyetlerinde olduğu gibi müzik öncelikle keyifli olduğu için icra ediliyor ve müziğin sağladığı ișlevler, kasıtlı biçimde amaçlanmadan (ya da kendiliğinden) gerçekleșiyor olabilir.

\section{Vokal Öğrenme: Balina Şarkılarının Bilișsel Temeli}

Zoomüzikolog Dario Martinelli, John Blacking'in ünlü etnomüzikolojik sorusunu (İnsan nasıl/ne kadar müzikaldir?), müzik olgusuna dair merakımızı insan türünün sınırlarının dıșına taşıyacak biçimde yeniden sorar: "Bir balina nasıl/ne kadar müzikaldir?". Blacking'inyaklaşımı, insankültürlerinive müziklerini belirli bir değer hiyerarșisine oturtan söylemin dișına çıkarak, tüm müzik kültürlerinin araștırılmaya ve anlaşılmaya değer olduğunun altını çizer. Çünkü Blacking'in yaklașımı ve temel sorusu bir tür olarak insanın müziği; üretebilme, algılayabilme ve müziğin barındırdığı kod ve anlamları çözebilme kapasitesine işaret eder. Martinelli'nin sorusu da aynı minvalde, örüntüleștirilen diziler olarak müzikal nitelikli sesleri üretebilme ve algılayabilme kapasitesine odaklanır. Balina șarkısı olarak adlandırılan hiyerarşik biçimde yapılandırılmış ses dizilerinin üretilmesi ve değerlendirilmesi, tıpkı insan müziğindeki gibi, türün tüm bireylerince paylaşılan belirli bir biyolojik kapasiteye (müzikalite) ve topluluk içi etkileșimler yoluyla edinilen sosyal öğrenme süreçlerine yaslanır. Bu noktada "vokal öğrenme" kritik bir kavramdır.

Vokal (sesli) öğrenme, iletișim sürecinin birkaç farklı yönü ile ilgilidir. Bağlamsal sesli öğrenme, mevcut sinyallerin yeni bağlamlarla ilișkilendirilmesidir. Bu, bir sinyalin/çağrının ne zaman, nerede kullanıldığının veya çağrının topluluk içindeki anlamının öğrenilmesidir. Vokal öğrenmede bir bașka yön, bir bireyin, diğer bireylerin ürettiği çağrıları işiterek kendi vokal sinyallerini belirli bir formda değiştirmeyi (ya da yeniden üretmeyi) öğrenmesidir. "Bu, yeni sinyallerin üretimini veya bir hayvanın repertuarında zaten bulunan sinyallerin modifiye edilmesini içerir. Vokal öğrenme, genellikle yeni sinyal türlerini ve bunların ne zaman kullanılacağını öğrenerek üretim ve bağlamsal öğrenmeyi birleștirir" (Janik, 2014:60). Bir önceki bölümde kambur balinaların, vokal öğrenmenin belirli bir biçimine (șarkı öğrenme) sahip olduklarını gösteren çeșitli olgulardan söz edilmiști: bir popülasyonda belirli bir zamanda tüm șarkıcı erkeklerin aynı șarkıyı söylemesi, coğrafi olarak yakın popülasyonlarda șarkıların da benzer olması, şarkıların üreme mevsimi boyunca giderek karmașıklașması ve bașka bir popülasyonun șarkısının hızla benimsenmesi. Şarkı öğrenme, vokal 
öğrenmenin, melodik, ritmik ve tınısal özellikleri barındıran özel bir biçimidir.

$\mathrm{Bu}$ tür bir vokal öğrenme becerisi doğada pek yaygın değildir, zira şimdiye kadar, deniz memelileri, yüzgeçayaklılar, yarasalar, filler ve insanlar da dahil olmak üzere yalnızca birkaç memeli grubunun bunu yapabildiği tespit edilmiștir. Öğrenme ve șarkı üretimi, (birkaçını saymak gerekirse) ötücü kușlar, fareler ve insanlar için beyindeki farklı yollarla eșleștirilebilse de bu henüz büyük, serbest dolașan deniz memelileri için mümkün değildir. Büyük deniz memeli türlerini incelerken önemli bir sınırlama, kontrollü laboratuvar deneyleri yapamamaktır (Garland vd. 2017:7823).

1970'lerden itibaren kambur balina șarkısına dair biriken veri, ötücü kușların șarkıları ile karșılaștırmalı biçimde değerlendirilmiş ve ötücü kușlar ile balinaların vokal öğrenme süreçlerinde ve dolayısıyla şarkılarında bazı farklar tespit edilmiștir. "Kuşlarda șarkı gelișimi tipik olarak, yapı ve içerik anlamında sabit hale gelen, 'kristalleșmiș’ nihai bir yetișkin şarkısına (veya șarkılar dizisine) doğru ilerleme biçimindedir" (Marcedo vd, 2005:93). Oysa kambur balinalar, tıpkı insanlar gibi, türe özgü nihai bir yetișkin șarkısında birleșmeyip yașam boyu yeni șarkılar öğrenebilirler. Kuș șarkıları ile karșılaștırıldığında kambur balina şarkısının spektral anlamda (seslerin tınısal ve perde çeșitliliği) daha esnek olmasının da bu yașam boyu öğrenme becerisi ile ilgili olması muhtemeldir.

Kambur balina şarkılarına ilișkin bir bașka ilginç nokta, bu vokal seslendirmelerin kafiyeli nakaratlar içermesidir. Araștırmacılar, kambur balinaların uzun, karmașık ses dizilerini ezberlemek için aynı zamanda anımsatıcı bir araç olarak kafiyeyi de kullandığını düșünmektedir (Angier, 2001). Bu durum, kambur balinaların hiyerarșik biçimde yapılandırılmıș vokal pratikleri ile insan müziği arasındaki bir bașka benzerliğe ișaret etmektedir.

Balina șarkısı ile insan müzıği arasındaki benzerlikler, son elli yılda, insan toplumlarının balinalara olan bakıșını da önemli ölçüde değiștirmiștir. Bu önemli dönüșümün gerçekleșmesinde prodüktörlüğünü Roger Payne'in yaptığı ve yalnızca kambur balinaların vokal seslendirmelerini içeren bir plak etkili olmuștur: Songs of the Humpback Whales. 1970 tarihinde piyasaya sürülen bu albüm, yüz binden fazla kopya satarak tarihin en çok satan çevre albümü olmuștur. "Albüm, balinaların zekâsı ve kültürü hakkında farkındalığı artırarak, dünya çapında bir 'Balinaları Kurtar' hareketinin doğmasına yardımcl olmuș ve 1972 Birleșmiș Milletler İnsan Çevresi Konferansı'nda, birkaç ülke dıșında herkes tarafından uyulan ticari balina avcılığı üzerine on yıllık küresel moratoryumu sağlamıștır" (O'Dell: 2021). Whitehead ve Rendell'a göre balinalara ilișkin bu algısal dönüșümün zamanlaması çok önemlidir. Zira 1960'lara gelindiğinde, balina avcılığı nedeniyle balina nüfusu tehlikeli oranda azalmıștır. Ancak Payne'in yayınladığı ses kayitlarından haberdar olan insanlar, șarkı söyleyen bir türe karșı artık eskisi kadar duyarsız ve yabancı kalamamıștır (2015:76-77). Günümüzde balina avcılığı dünyanın yalnızca çok kısıtlı bir bölgesinde sürdürülmektedir. Kambur balina nüfusu eskiye oranla artmış olsa da küresel ısınma, deniz 
kirliliği ve okyanuslarda insan kaynaklı gürültü yoğunluğu, hem balinaların yașam koșullarını zorlaștırmakta hem de balina şarkısının ideal icra şartlarını kısıtlamaktadır.

\section{Sonuç}

Dișsiz ya da çubuklu balinalar (baleen whales) alt sınıfına dahil olan mavi balina, kambur balina ve güney gerçek balinası gibi türler, kısa ve basit sosyal çağrılara ek olarak uzun, karmașık ve tınısal açıdan zengin vokal diziler seslendirirler. 1970'li yıllarda kambur balinaların, uzun ve karmaşık vokal gösterilerinin sualtı mikrofonları ile alınmıș kayıtları, deniz biyologları tarafından ayrıntılı biçimde incelenmiștir. Roger Payne, Kathy Payne, Scott McVay ve Howard Winn, bu ses kayıtlarının sonogram görüntülerini de analiz ettikten sonra erkek kambur balinaların uzun, karmaşık icralarının, öngörülebilir hiyerarșik bir yapıya sahip olduğunu tespit etmiș ve bilimsel literatüre "balina șarkısı" terimini kazandırmıșlardır.

Kambur balina şarkıları, iç içe geçmiş ve hiyerarşik biçimde örgütlenmiş ses dizilerinden meydana gelir. Kambur balina șarkısında nota benzeri tekil birimler (heceler) bir araya gelerek cümleleri, art arda dizilen cümleler temaları, belirli biçimlerde düzenlenen ve tekrarlanan temalar ise ortalama 10 - 15 dakikalık șarkıları olușturur. Bir şarkı tamamen aynı biçimde ya da cümle ve temaların tekrarlarında farklar olacak sekilde saatlerce icra edilebilir. Araștırmacılar, bu uzun șarkı performanslarına "șarkı döngüsü" adını vermișlerdir. Şarkı icra etmek yalnızca erkek kambur balinaların sergilediği bir davranıștır ve sosyal etkileșimde önemli bir yer tutar. Dișiler ve yavrular ise sadece daha kısa ve basit sosyal çağrılar ile iletișim kurarlar.

Hayli göçmen bir tür olan kambur balinalar, doğada bilinen en uzun göç rotalarına sahiptir. Yazın kutup bölgelerine yakın ve yiyecek açısından zengin, yüksek enlemli soğuk sularda beslenirler. Kıș için ekvatora yakın, sıcak, sığlık alanlara göç ederler. Bu bölgeler aynı zamanda kambur balina popülasyonlarının önceki kuşaklardan devraldıkları çiftleșme ve üreme alanlarıdır. Erkek kambur balinalar, kimi zaman göç sırasında ama çoğunlukla bu üreme alanlarında șarkı icra ederler ki bu, șarkı söylemenin bir kur davranıșı olması ihtimalini yükseltir. Ancak gözlemler henüz dișilerin șarkılardan etkilenerek eș seçtiklerini doğrulamamıștır. Dolayısıyla şarkı icralarının aynı zamanda dișilere konum bildirmek ve diğer erkeklere belli mesajlar iletmek amacıyla yapılması da muhtemeldir.

Üreme mevsimi boyunca bir popülasyondaki tüm erkek balinalar, birbirilerini taklit ederek, tek bir șarkının mevcut biçimine uyum sağlasalar da icralarda bireysel farklılıklar olușur. Bu süreç șarkıyı kademeli olarak karmașıklaștırır, dönüștürür ve sonunda artık yeni bir șarkı inșa edilmiş olur. Şarkıların kademeli dönüșümü ve kimi zaman gerçekleșen hızlı değișimler, iki olgunun varlığına ișaret eder: (1) kambur balinalar, "vokal öğrenme" becerisine sahip bir türdür ve (2) kambur balina popülasyonları arasında kültürel aktarım söz konusudur. Bu kültürel aktarım, șarkıların kademeli dönüșümü ile birlikte düșünüldüğünde, kambur balina şarkılarının yalnızca içgüdü ile sınırlı bir olgu olmayıp, insan müziğini anımsatır biçimde, akustik/müzikal bir kültür olduğu görülebilir. 
Kambur balinaların șarkıları aynı zamanda soyu tükenme riski altında olan bu canlılar için bir tür can simidi ișlevi de görmüștür. 1970'de Roger Payne'in prodüktörlüğünde piyasaya sürülen ve yalnızca kambur balinaların vokal kayıtlarını içeren bir plak, yüz binden fazla kopya satarak kambur balinaları hayranlık duyulan bir türe ve okyanustaki canlı çeșitliliğinin korunması anlamında bir ikona dönüștürmüștür. Ancak günümüzde küresel ısınma, okyanuslardaki kirlilik ve așırı avlanmanın yanı sıra ticari faaliyetlerden kaynaklanan düşük frekanslı gürültüler, balinaların müzikal kültürlerini tehdit etmeye ve hayatta kalma kapasitelerini olumsuz yönde etkilemeye devam etmektedir. Bu nedenle balinaların, insan müziği ile benzer yönleri olan bir müzikal kültüre sahip oldukları bilgisinin yaygınlașması, okyanuslardaki büyük yırtıcı türlerin korunması yönünde duyarlılığı artırabilir. 


\section{Yazar Biyografisi}

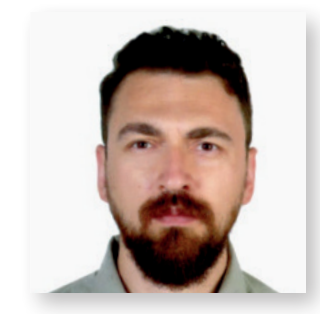

\section{Dr. Öğr. Üyesi Ali Keleș}

Lisans ve yüksek lisans eğitimini Mimar Sinan Güzel Sanatlar Üniversitesi Sosyoloji Bölümü’nde tamamlamıștır. “Ortak Kimlik ve Müzik: 1980 Sonrası Alevi-Bektaşi Uyanışı” adlı yüksek lisans tezini Prof. Dr. Meral Özbek danıșmanlığında yazmıștır. Doktorasını 2016 yılında, Dokuz Eylül Üniversitesi Güzel Sanatlar Enstitüsü Müzik Bilimleri Programı'nda, Prof. Dr. Ayhan Erol danıșmanlığında yazıp savunduğu "Alevi Müzik Uyanışının Eğitim Bileșeni: Şahkulu Sultan Dergahı ve Erdal Erzincan Müzik Merkezi” adlı tez ile tamamlamıștır. 2018 yılından beri Trabzon Üniversitesi Devlet Konservatuvarı Müzikoloji Bölümü’nde Dr. Öğr. Üyesi olarak görev yapmaktadır. İlgi ve çalıșma alanları; müzik sosyolojisi, kültürel kimlik - müzik ilișkisi, popüler müzik araștırmaları, zoomüzikoloji ve biyomüzikoloji incelemeleridir. 
Kaynakça

Adam, O., Cazau, D., Gandilhon, N. vd. (2013) "New Acoustic Model for Humpback Whale Sound Production", Applied Acoustics 74 (2013) 1182-1190.

Allen, J. A., Garland E. C., Dunlop R. A., Noad M. J. (2018) "Cultural Revolutions Reduce Complexity in the Songs of Humpback Whales", Proc. R. Soc. B 285: 20182088.

Arraut, E. M., Viellilard J. M. (2004) "The Song of The Brazilian Population of Humpback Whale Megaptera Novaeangliae, in the Year 2000: Individual Song Variations and Possible Implications", Annals of the Brazilian Academy of Sciences, 76(2): 373380.

Aydın, M. (2020) Luscinia Megarhynchos (Bülbül) Şarkılarının Etnografik Ornitomüzikoloji İncelemesi, yayınlanmamıș yüksek lisans tezi, İstanbul Üniversitesi Sosyal Bilimler Enstitüsü Müzikoloji Anabilim Dalı.

Cholewiak, D. M., Sousa-Lima R. S. (2013) "Humpback Whale Song Hierarchical Structure: Historical Context and Discussion of Current Classification Issues", Marine Mammal Science, 29 (3): 312-332 (July 2013).

Clapham, P. J. ve Mead, J. G. (1999) "Megaptera novaeangliae", Mammalian Species No. 604, 1-9.

Clapham P. J. (2002) "Humpback Whale Megaptera Novaeangliae", Encyclopedia of Marine Mammals, (ed.) William Perrin, Bernd Würsig, J. G. M. Thewissen, Academic Press, California, USA, 589-592.

Darling, J. (2002) “Song”, Encyclopedia of Marine Mammals, (ed.) William Perrin, Bernd Würsig, J. G. M. Thewissen, Academic Press, California, USA, 1124-1126.

Doolittle, E. ve Gingras, B. (2015) "Quick Guide: Zoomusicology", Current Biology 25, 5 October 2015, 811-812.

Fournet, M. E. H. (2014) Social Calling Behavior of Southeast Alaskan Humpback Whales (Megaptera Novaeangliae): Classification and Context, yayımlanmamıș yüksek lisans tezi, Oregon State University, Oregon, ABD.

Garland, E. C., Goldizen, A. W., Rekdahl, M. L. vd (2011) "Dynamic Horizontal Cultural Transmission of Humpback Whale Song at the Ocean Basin Scale", Current Biology 21, April 26, 2011, 687-691.

Garland, E. C., Rendell, L., Lamoni L. vd. (2017) “Song Hybridization Events During Revolutionary Song Change Provide Insights into Cultural Transmission in Humpback Whales", PNAS, July 25, 2017, vol. 114, no. 30, 7822-7829.

Geissmann, T. (2000) "Gibbon Songs and Human Music from an Evolutionary Perspective", The Origins of Music, (Ed.) Nils L. Wallin, Björn Merker, Steven Brown, The MIT Press, 103-123.

Herman, L. M. vd (2013) "Humpback Whale Songs: Who Sings?", Behavioral Ecology and Sociobiology (2013) 67: 1653-1663.

Janik, V. (2014) “Cetacean Vocal Learning and Communication", Current Opinion in Neurobiology, 2014, 28:60-65.

Kavanagh Ailbhe S. vd. (2016) "Evidence for The Functions of Surface-Active Behaviors in Humpback Whales (Megaptera 
Novaeangliae)", Marine Mammal Science, 33(1): 313-334.

Keleș, A. (2021) "Zoomüzikoloji Penceresinden Kültür Olarak Müzik", 11. Uluslararası Hisarlı Ahmet Sempozyumu Tam Metin Kitabı, (Ed.) Çağhan Adar ve Filiz Yıldız, ss. 9-19, İzge Basın Yayın: Ankara.

Marcedo, E., Herman L., Pack A. (2005) "Song Copying by Humpback Whales: Themes and Variations", Animal Cognition (2005) 8: 93-102.

Martin, S., Aniceto, A. S., Ahonen, H. (2021) "Humpback Whale (Megaptera novaeangliae) Song on a Subarctic Feeding Ground", Frontiers in Marine Science, May 2021, Vol. 8.

Martinelli, D. (2005) "A Whale of a Sonata Zoomusicology and the Question of Musical Structures", S.E.E.D. Journal, September 2005, Volume 5, No. 1, s. 2-29.

Martinelli, D. (2007) Zoosemiotics: Proposals for a Handbook, Imatra: International Semiotics Institute.

NMFS (National Marine Fisheries Service) (1991) Recovery Plan for the Humpback Whales (Megaptera novaeangliae). Prepared by the Humpback Whale Recovery Team for the National Marine Fisheries Service, Silver Spring, Maryland, 105 pp.

Noad, M. J., Cato, D.H. vd (2000) "Cultural Revolution in Whale Songs", Nature, Vol. 408, 30 November 2000, 537.

O'Dell, C. (2021) "Songs of the Humpback Whale", Library of Congress, (https:// www.loc.gov/static/programs/nationalrecording-preservation-board/documents/ humpback\%20whales.pdf) (Erişim Tarihi:
Ağustos 2021).

Payne, R. S., McVay, S. (1971) "Songs of Humpback Whales", Science, 13 August 1971, Volume:173, Number 3997, pp. 585-597.

Perrin, W. F., Würsig, B., Thewissen J. G. M. (2002) Encyclopedia of Marine Mammals, (ed.) William Perrin, Bernd Würsig, J. G. M. Thewissen, Academic Press, California, USA.

Sorce Keller, M. (2012) "Zoomusicology and Ethnomusicology: A Marriage to Celebrate in Heaven", Yearbook for Traditional Music, Vol. 44 (2012), pp. 166-183.

Taylor, H. (2020) "How Musical Are Animals? Taking Stock of Zoömusicology's Prospects." Music Research Annual 1: 1-35.

Whitehead, H. ve Rendell, L. (2015), The Cultural Lives of Whales and Dolphins, The University of Chicago Press, Chicago and London.

Welch, C. (2021) "Balina Sirları" National Geographic, Özel Sayı: Okyanuslar, Mayıs 2021, 34-65.

\section{İnternet Kaynakları}

Link 1: International Whaling Commission: "Humpback Whale - Megaptera novaeangliae"

https://iwc.int/humpback-whale

Figür 1: Hawaii Marine Mammal Consortium https: / /www.hmmc.org/Song/HBWsong. html

Figür 2: Hawaii Marine Mammal Consortium https: / / www.hmmc.org / AudioGallery/ AudioGallery.htm 


\section{Whale Song: Musical Practices in the Cultures of the Humpback Whale Megaptera Novaeangliae}

\section{Extended Abstract}

The vocal practices and songs of humpback whales have been the subject of much research in terms of function, temporal change, hierarchical structure, complexity and meaning. These studies, which need an interdisciplinary approach, are nowadays; continues to attract scientists from many fields such as ethology, marine biology, evolutionary anthropology, bioacoustics, zoomusicology, ethnomusicology, linguistics and cognitive psychology. The purpose of this article is to present the findings of whale song research and zoomusicological studies within the framework of vocal learning and in relation to our understanding of music. For this purpose, the basic research method on which the study is based is literature review. The literature of different disciplines such as marine biology, bioacoustics, ethology, zoomusicology and ethnomusicology has been examined on the axes of animal music, vocal learning and whale song, and the relevant findings have been compiled.

Humpback whales, which have an average lifespan of 60 years and are among the largest living animal species, are taxonomically included in the baleen whales suborder of the cetacean order. Developed vocal practices which are the most interesting elements of humpback whale cultures, have made this species one of the focus of marine biology and also zoomusicology. In the 1970s, hydrophone recordings of long and complex vocal performances by humpback whales were studied in detail by marine biologists. After analyzing the sonogram images of these sound recordings Roger Payne, Kathy Payne, Scott McVay, and Howard Winn determined that the long, complex performances of male humpback whales had a predictable hierarchical structure and introduced the term "whale song" to the scientific literature.

Male humpback whales (Megaptera novaeangliae) display long, complex and patterned vocalization practices called "whale song". Although the function of songs is not yet fully understood, it is likely that they are both a courtship behavior and a form of communication that gives various messages to other male individuals. Songs are made up of various hierarchically arranged units and repetitions: single notes-like units form sentences, sentences combined together form themes. The themes that are organized and recurring in certain ways make up the songs. Humpback whales in the same population sing the same song within a certain period of time. However, during the season, due to the deformation of the sound units, the changing of the order or the repetition, the songs become more and more complex and turn into completely new songs. Humpback whale songs have similarities with human music due to their arranged/ patterned structure and transmission between individuals and communities.

Michael Noad, Ellen C. Garland and their colleagues, who approached the transformation of humpback whale songs at different populations level, found that there was a continuous cultural transfer from west to east. Thus a "cultural revolution" for humpback whale song was first voiced, as songs performed at the mating and breeding grounds on the west coast of Australia were also sung by humpback whales on the east coast after just a few seasons.

Zoomusicologist Dario Martinelli re-asks John Blacking's famous ethnomusicological question in a way that takes our curiosity about the phenomenon of music beyond the limits of the human species: "How musical is a whale?". Blacking's approach and basic question point to the capacity of human beings to produce and perceive music and to decode the codes and meanings of music. In the same way, Martinelli's question focuses on the capacity to produce and perceive musical sounds as patterned sequences. The production and evaluation of hierarchically structured 
sound sequences, called whale songs, relies on a certain biological capacity (musicality) shared by all individuals of the species and social learning processes acquired through intra-communal interactions, just as in human music. At this point, "vocal learning" is a critical concept.

Vocal learning is concerned with several different aspects of the communication process: (1) associating existing signals with new contexts, (2) an individual learning to modify (or reproduce) vocal signals in a particular form by hearing the calls produced by other individuals. The ability to learn songs is a special form of vocal learning that includes melodic, rhythmic and timbre features. This skill possessed by humpback whales is not very common in nature. Moreover, unlike songbirds, humpback whales can learn new songs throughout their lives, just like humans.

The songs of humpback whales served as a kind of savior for these creatures, which were at risk of extinction. Produced by Roger Payne in 1970, a record containing only vocal recordings of humpback whales has sold more than a hundred thousand copies, making humpback whales an adored species and an icon for preserving ocean diversity. Today, however, global warming, ocean pollution and overfishing, as well as low-frequency noise from commercial activities continue to threaten the musical culture of whales and adversely affect their survival capacity. Therefore, spreading the knowledge that whales have a musical culture that has similarities with human music may increase awareness for the protection of large predatory species in the oceans.

\section{Keywords}

zoomusicology, whale song, humpback whale, vocal learning 
